\section{References}

1. Anneren G, Sedin G (1981) Trisomy 9 syndrome. Acta Paediatr Scand 70: $125-128$

2. Carpenter BF, Tomkins DJ (1982) Trisomy 9-syndrome. Persp Pediatr Pathol 7: 109-120

3. Ginsberg J, Soukup S, Bendon RW (1989) Further observations of ocular pathology in trisomy 9. J Pediatr 26: 146-149

4. Zadeh TM, Peters J, Sandlin C (1987) Prenatal diagnosis of mosaic trisomy 9. Prenat Diagn 7: 67-70

5. Chitkara V, Cogswell C, Norton K et al. (1988) Choroid plexus cysts in the fetus: a benign anatomic variant or pathologic entity? Report of 41 cases. Obstet Gynecol 72: 185-189

6. Fitzsimmons J, Wilson D (1989) Choroid plexus cysts in fetuses with Trisomy 18. Obstet Gynecol 73: 257-260

7. Furness M (1987) Choroid plexus cyst and Trisomy 18. Lancet I: 693

8. Ostlere SJ, Irving HC, Lilford RJ (1987) Choroid plexus cysts in the fetus. Lancet II: 1491

9. Nakamura Y, Hashimoto T, Sasaguri Y et al. (1986) Brain abnormalities found in 18 Trisomy: CT scanning, morphology and morphometric study. Clin Neuropathol 5: 47-52

10. Sperber G, Honore L, Machin G (1989) Microscopic study of holoprosencephalic facial anomalies in Trisomy 13 fetuses. Am J Med Genet 32: 443-451

11. Moerman P, Fryns JP, van der Steen K et al. (1988) Pathology of Trisomy 13 syndrome. Hum Genet 80:349-356

12. Leech RW, Shuman RM (1986) Holoprosencephaly and related midline cerebral anomalies. A review. J Child Neurol 1:3-18
13. Nyberg DA, Mack LA, Bronstein A, Hirst J, Pagon RA (1987) Holoprosencephaly: Prenatal sonographic diagnosis. AJR 149: 1051-1058

14. Cohen MM (1982) An update of the holoprosencephalic disorders. J Pediatr 101: 865-869

15. Teele RL, Hernanz-Schulman M, Sotrel A (1988) Echogenic vasculature in the basal ganglia of neonates: a sonographic sign of vasculopathy. Radiology 169: 423-427

16. Ben-Ami T, Yousefzadeh D, Backus M, Rerchman B et al. (1990) Lenticulostriate vasculopathy in infants with infections of the CNS: Sonographic and Doppler findings. Pediatr Radiol 20: 575 579

17. Kinoshita M, Nakamura Y, Nakano R et al. (1989) Thirty-one autopsy cases of Trisony 18. Pediatr Pathol 9:445-457

18. Thurmond A, Nelson DW, Lowensohn RI (1989) Enlarged cisterna magna in Trisomy 18. Prenatal ultrasonographic diagnosis. Am J Obstet Gynecol 161:83-85

19. Moore CA, Harmon JP, Padella LM, Castro VP (1988) Neural tube defects and omphalocele in Trisomy 18. Clin Genet 34: 98103

\section{Dr. T.E.Herman}

Mallinckrodt Institute of Radiology

Washington University School of Medicine

510 South Kingshighway Boulevard

St. Louis, Missouri 63110

USA

\title{
Literature in pediatric radiology
}

\section{American Journal of Diseases of Children (Chicago)}

Radiological case of the month: Cavitary pne umonia due to arcanobacterium hemolyticum. Waller, K.S. et al. (Dept. of Rad., Children's Hosp. of Los Angeles, 4650 Sunset Blvd, Los Angeles, CA 90027, USA) 145, 209 (1991)

Late cholangitis after successful surgical repair of biliary atresia. Gottrand, F. et al. (Dept. of Ped., Claude Huriez Hosp., Univ. Hosp. of Lille, 59037 Lille, France) 145, 213 (1991)

Radiological case of the month: A pediatric case of Eagle's syndrome. Holloway, M. K. et al. (Dept of Rad., Children's Hosp. of Los Angeles, 4650 Sunset Blvd, Los Angeles, CA 90027 , USA) 145, 339 (1991)

Radiological case of the month: Laron-type dwarfism. Allison, J.W. et al. (Dept. of Rad., Children's Hosp. of Los Angeles, 4650 Sunset Blvd, Los Angeles, CA 90027, USA) 145, 471 (1991)

American Journal of Human Genetics (Chicago)

Mild spondyloepiphyseal dysplasia (namaqualand type): Genetic linkage to the type II collagen gene (COL2AI) Sher, C. et al. (P.Beighton, Dept. of Human Genetics, Univ. of Cape Town Med. Sch., Observatory 7925, Cape Town, South Africa) 48, 518 (1991)

Clinical and Molecular diagnosis of Miller-Dieker syndrome. Dobyns, W.B. et al. (Dept. of Neurol., Room N102, Riley Hosp., Indiana Univ., 702 Barnhill Drive, Indianapolis, IN 46202-5200, USA) 48, 584 (1991)

\section{American Journal of Neuroradiology (Baltimore)}

Gadopentetate dimeglumine-enhanced MR imaging in children following surgery for brain tumor: spectrum of meningeal findings. Hudgins, P. A. et al. (Dept. of Rad., Section of Neurorad., Emory Univ. School of Med., 1364 Clifton Rd., N.E., Atlanta, GA 30322, USA) 12, 301 (1991)

Hamartomas of the tuber cinereum: CT, MR, and pathologic findings. Boyko, O. B. et al. (Dept. of Rad., Duke Univ. Med. Center, Durham, NC 27710 , USA) 12,309 (1991)

Vein of Galen malformation: correlation of clinical presentation, arteriography, and MR imaging. Seidenwurm, D. et al. (Dept. of Rad., Peninsula Hosp., 1783 EL Camino Real, Burlingame, CA 94010, USA) 12, 347 (1991)

Cranial MR imaging in rhizomelic chondrodysplasia punctata. Williams III, D. W. et al. (Elster, A.D., Dept. of Rad., The Bowman Gray School of Med., Wake Forest Univ., $300 \mathrm{~S}$. Hawthorne Rd., Winston-Salem, NC 27103, USA) 12, 363 (1991)

* Compiled by Professor Willich, Heidelberg
Cystic intraparenchymal meningioma in a child: case report. Mamourian, A.C. et al. (Dept. of Rad., Milton S. Hershey Med. Center, Hershey, PA 17033, USA) 12,366 (1991)

Contrast-enhanced MR imaging of neurocutaneous melanosis. Rhodes, R.E. et al. (Dept. of Rad., Duke Univ. Med. Center, Box 3808, Durham, NC 27710, USA) 12, $380(1991)$

American Journal of Roentgenology (Baltimore)

Bronchopulmonary dysplasia and research in diagnostic radiology. Northway, Jr., W.H. (Dept. of Diagn. Rad. and Nucl. Med., Univ. Med. Center, Stanford, CA 94305, USA) 156, 681 (1991)

Extension of growth-plate cartilage into the metaphysis: a sign of healing fracture in abused infants. Kleinman, P. K. et al. (Dept. of Rad., Univ. Med. Center, 55 Lake Av. N., Worcester, MA 01655, USA) 156, 775 (1991)

Normal metaphyseal radiologic variants not to be confused with findings of infant abuse. Kleinman, P. K. et al. (Dept. of Rad., Univ. Med. Center, 55 Lake Av., N., Worcester, MA 01655, USA) 156, 781 (1991)

Osteomyelitis of the talus: an unusual cause of limping in childhood. GrattanSmith, J.D. et al. (Wagner, M. L., Dept. of Rad., Children's Hosp. and Baylor College of Med., 6621 Fanin, Houston, TX 77030, USA) 156, 785 (1991)

MR evaluation of spinal dermal sinus tracts in children. Barkovich, A. J. et al. (Dept. of Rad., Box 0628, Neurorad. Section, L371, Univ., San Francisco, CA 94143, USA) 156, 791 (1.991)

Polysplenia syndrome with congenital short pancreas. Herman, T.E., Siegel, M. J. (Mallinckrodt Inst. of Rad., Washington Univ. School of Med., 510 S. Kingshighway Blvd., St. Louis, MO 63110, USA) 156, 799 (1991)

Imaging of the azygos lobe: Normal anatomy and variations. Mata, J. et al. (Serv. de Rad., Hosp. de Sant Pau, Fac. de Med., Univ. Autonoma, Avda. S. Antonio M. Claret, 167, 08025 Barcelona, Spain) 156, 931 (1991)

Yersinia terminal ileitis: Sonographic findings in eight patients. Matsumoto, T. et al. (Second Dept. of Internal Med., Fac. of Med., Kyushu Univ., Maidashi 3-1-1, Higashi-ku, Fukuoka 812, Japan) 156, 965 (1991)

Fibrous dysplasia vs adamantinoma of the tibia: Differentiation based on discriminant analysis of clinical and pain film findings. Bloem. J.L. et al. (Dept. of Rad., Bldg. I, C2-S, Univ. Hosp. Leiden, Rijnburgerweg 10, 2333 AA Leiden, Netherlands) 156, 1017 (1991)

Interobserver and intraobserver variations in sonographic renal length measurements in children. Schlesinger, A.E. et al. (Dept. of Rad., Univ, of Michigan Hosp., 1500 E. Med. Center Dr., Ann Arbor, MI 48109, USA) $156,1029(1991)$ 
above an area of narrowing should suggest a secondary pulsion diverticula above a foreign body. This is particularly true when the level of the neck of the diverticulum is above the thoracic inlet or the aortic arch, common foreign body sites.

\section{References}

1. Towbin R, Lederman HM, Dunbar JS, Ball WS, Strife JL (1989) Esophageal edema as a predictor of unsuccessful balloon extraction of esophageal foreign bodies. Pediatr Radiol 19:359

2. Ramadan MF, Rogers TH (1981) An acquired oesophageal pouch in childhood: a problem of diagnosis. J Laryngol Otol 95: 101

3. Newman DE (1978) Radiolucent esophageal foreign body: an often-forgotten cause of respiratory symptoms. J Pediatr 92:60

4. Smith P, Swischuk LE, Fagan CJ (1974) Elusive and often unsuspected cause of stridor or pneumonia - the esophageal foreign body. AJR 122: 80
5. Meadows JA (1970) Esophageal diverticula in infants and children. South Med J 63: 691

6. Osman MZ, Girdany BR (1973) Traumatic pseudodiverticulum of the pharynx in infants and children. Ann Radiol 16: 143

7. Dubos B, Ropulaud V, Morisot C (1983) Perforations et ruptures de l'esophage chez le nouveau-ne. Med Inf 93: 269

8. Toyohara T, Kaneko T, Araki H, Takahasi K, Nakamura T (1989) Giant epiphrenic diverticulum in a boy with Ehlers-Danlos syndrome. Pediatr Radiol 19:437

9. Theander G (1973) Congenital poserior midline pharyngoesophageal diverticula. Pediatr Radiol 1: 153

\section{Dr.T.E.Herman}

Mallinckrodt Institute of Radiology

Washington University School of Medicine

510 South Kingshighway Boulevard

St. Louis, Missouri 63110

USA

\section{Literature in pediatric radiology (continued from $p .401$ )}

Anomaly of the descending aorta: A case of persistent double dorsal aorta. Formanek, A. G. et al. (Dept. of Rad., Bowman Gray Sch. of Med., 300 S. Hawthorne Rd., Winston-Salem, NC 27103, USA) 156, 1033 (1991)

Primary lymphoma of the CNS in an infant with AIDS: Imaging findings. Douek, P. et al. (Dept. of Ped.-Rad., UFR Lyon-Nord and Hôp. Debrousse, 29 rue Soeur Bouvier, F-69322 Lyon, France) 156, 1037 (1991)

Hamartomas of the tuber cinereum: CT, MR, and pathologic findings. Boyko, O. B. et al. (Dept. of Rad., Duke Univ. Med. Center, Durham, NC 27710, USA) 156, 1053 (1991)

Imaging characteristics of tuberous sclerosis. Bell, D. G. et al. (Mayo Clin. Foundation, 200 First St., S.W., Rochester, MN 55905, USA) 156, 1081 (1991)

Safety-belt injuries in children with lap-belt ecchymosis: CT findings in 61 patients. Sivit, C. J. et al. (Dept. of Diagn. Imaging and Rad. and Ped., Children's National Med. Center, 111 Michigan Ave., N. W., Washington, DC 20010, USA) 157, 111 (1.991)

Urinary tract calculi that form on surgical staples: A characteristic radiologic appearance. Dangman, B. C., Lebowitz, R.L. (Dept. of Rad., Children's Hosp., 300 Longwood Ave., Boston, MA 02115, USA) 157, 115 (1991)

Normal splenic size in infants and children: Sonographic measurements. Rosenberg, H.K. et al. (Dept. of Rad., Div. of Ultrasound, The Children's Hosp. of Philadelphia, 34th St., Civic Center Blvd., Philadelphia, PA 19104, USA) 157, 119 (1991)

Radiologic evaluation of the normal and diseased posterior cervical space. Parker, G.D., Harnsberger, H. R. (Dept. of Rad., Univ. of Utah Sch. of Med., 50 N. Med. Dr, Salt Lake City, UT 84132, USA) 157, 161 (1991)

Applied Radiology (Port Washington)

An unusual cause of an abdominal mass in the neonate. Jones, B.E., Lawrence, D. (Dept. of Rad. at the Univ. of Rochester, NY, USA) 19, 36 (1990)

Interventional radiology: Congenital dysplasia of the hip. Beim, G.M. et al. (Dept. of Rad at the San Diego Med, Center, San Diego, CA, USA) 20, 10 (1991)

Radiological case of the month: Focal nodular hyperplasia. Johnson, W.K., Auringer, S. T. (Dept. of Rad., Bowman Gray Sch. of Med., WinstonSalem, NC, USA) 20, 21 (1991)

\section{Archives of Surgery (Chicago)}

Inflammatory pseudotumor in childhood. A diagnostic and therapeutic dilemma. Freud, E. et al. (Dept. of Ped.-Surg., Beilinson Med. Center, PetahTiqva, 49100, Israel) 126, 653 (1991)

Clinical Nuclear Medicine (Philadelphia)

Photopenic areas on bone scanning associated with childhood leukemia Morrison, St. C., Adler, L.P. (Dept. of Rad., Univ. Hosp. of Cleveland, 2074 Abington Road, Cleveland, OH 44106 USA) 16, 24 (1991)

Testicular scintigraphic findings two to three months after torsion. Correlation with sonography and histopathology. Dunn, E. K. et al. (Div. of Nuclear Med., Box 1210, SUNY Health Sci. Center at Brooklyn, 450 Clarkson. Ave., Brooklyn, NY 11203, USA) 16, 37 (1991)
A horseshoe kidney detected by abdominal scanning with Tc-99m labeled red blood cells. Morita, S. et al. (Dept. of Rad., Kurume Univ. Sch. of Med., 67 Asahimachi, Kurume City, Fukuoka, 830, Japan) 16, 194 (1991)

Scintigraphic findings mimicking focal nodular hyperplasia in a case of hepatoblastoma. Tanasescu, D.E. et al. (Thousand Oaks Rad. Group, 227 W. Janss Road, Ste. 150, Thousand Oaks, CA 91360, USA) 16, 236 (1991)

Low-grade vesicoureteral reflux variability in grade on sequential radiographic and nuclear cystograms. Gelfand, M.J. et al. (Sect. of Nuclear Med., Dept. of Rad., Children's Hosp. Med. Center, Cincinnati, OH 45229 2899, USA) 16, 243 (1991)

Torsion of an undescended testis not detected on testicular imaging. Dravid, V. S., Heyman, S. (Dept. of Rad., Children's Hosp. of Philadelphia, 34th and Civic Center Blvd, Philadelphia, PA 19104, USA) 16, 275 (1991)

Diffuse lung uptake of Tc-99m MDP associated with pneumocystis carinii pneumonia in a patient with neuroblastoma. Granville Batte, W., Jr. et al (S.D.J. Yeh, Memorial Sloan-Kettering Cancer Center, Nuclear Med. Serv., 1275 York Ave., New York, NY 10021, USA) 16, 321 (1991)

Vesicoureteric reflux at the end of renography. Dugal, B., Nerdrum, H.-J (Dept. of Clin. Chemistry, Sentralsykehuset i Akershus, 1474 Nordbyhagen, Norway) 16, 364 (1991)

Clinical Pediatries (Cleveland)

Abnormal sinus radiographs in children with a history of bronchopulmonary dysplasia. Cohn, R.C. (Dept. of Ped., Wright State Univ. and Children's Med. Center, Dayton, OH, USA) 30, 126 (1991)

Investigative Radiology (Philadelphia)

Observer variation in detecting the radiologic features associated with bronchiolitis. Coblentz, C.L. et al. (C. J. Babcook, Dept. of Rad., McMaster Univ. Med. Centre, 1200 Main St.West, Hamilton, Ontario L8N 375, Canada) 26, 115 (1991)

\section{Journal of Bone and Joint Surgery (Boston)}

Skeletal involvement in children who have chronic granulomatous disease. Sponseller, P.D. et al. (The Johns Hopkins Hosp., 600 North Wolfe St., CMSC 9-125, Baltimore, MD 21205, USA) 73-A, 37 (1991)

Familial cervical dysplasia. Saltzman, Ch.L. et al. (Univ. of Michigan, TC2912/03 28, 1500 East Med. Center Drive, Ann Arbor, MI 48109-0328, USA) 73-A, 163 (1991)

Chronic posterior subluxation and dislocation of the radial head. Bell, S.N. et al. (Mayo Clin., 200 First St S. W., Rochester, MN 55905, USA, A. J. Bianco, Jr) 73-A, 392 (1991)

Growth disturbance of the proximal part of the femur after treatment for congenital dislocation of the hip. Keret, D. et al. (Dept. of Med. Educat., Alfred I. duPont Inst., P. O. Box 269, Wilmington, Delaware 19899, USA) 73-A, 410 (1991)

Ipsilateral fractures of the femur and tibia in children and adolescents. Bohn, W.W., Durbin, R.A. (Res. Med. Center, Suite T-415, 6420 Prospect Ave., Kansas City, MS 64132, USA) 73-A, 429 (1991) 
struction, renal duplication, and megaureter and hydronephrosis, if US, VCUG and renal scintigraphy have produced corroborating findings. In this way, one examination with radiation exposure can be eliminated.

\section{References}

1. Hennig J, Friedburg H, Ströbel B (1986) Rapid nontomographic approach to MR-myelography without contrast agents. J Comput Assist Tomogr 10:375

2. Hennig J, Nauerth A, Friedburg H (1986) RARE imaging: A fast imaging method for clinical MR. Magn Res Med 3: 823

3. Hennig J, Friedburg H (1988) Clinical applications and methodological developments of the RARE technique. Magn Res Imag 6:391

4. Friedburg H, Hennig J, Frankenschmidt A (1987) RARE-MR urography: Imaging of the urinary tract with a new fast non-tomographic MR technique. Radiologe 27: 45 (In German, with English summary)

5. Friedburg H, Westenfelder M, Roeren T, Hennig J (1987) MR of the urinary tract in pregnancy. RoeFo 147: 430 (In German, with English summary)
6. Hennig J (1988) Multiecho imaging sequences with low refocusing flip angles. J Magn Res 78: 397

7. Mulkern RV, Wong STS, Winalski C, Jolesz FA (1990) Contrast manipulation and artifact assessment of 2D-and 3D-RARE sequences. Magn Res Imag 8: 557

8. Friedburg HG, Hennig J, Schumacher M (1987) Clinical application of RARE-MR-myelography as a routine MR examination: Experience with 175 cases. RoeFo 146: 584 (In German, with English summary)

9. Dietrich RB, Kangarloo H (1986) Kidneys in infants and children: evaluation with MR. Radiology 159:215

10. Jequier S, Paltiel H, Lafortune M (1990) Ureterovesical jets in infants and children: Duplex and color Doppler US studies. Radiology 175:349

11. Marshall JL, Johnson ND, DeCampo MP (1990) Vesicoureteric reflux in children: Prediction with color Doppler imaging. Work in progress. Radiology 175: 355

Dr. G. Sigmund

Abteilung Röntgendiagnostik,

Radiologische Klinik der

Universität Freiburg

Hugstetterstrasse 55

W-7800 Freiburg i.Br.

FRG
Literature in pediatric radiology (continued from p. 412)

Musculoskeletal problems in association with cloacal exstrophy. Greene, W. B. et al. (Div. of Orthopaedic Surg., Univ. of North Carolina Sch. of Med., Campus Box 7055, 242 Burnett-Womack Bldg., Chapel Hill, NC 27599-7055, USA) 73-A, 551 (1991)

Metachronous osteoid-osteomas. Report of a case. Larsen, L.J. et al. (Children's Hosp. of San Francisco, 3700 California St., San Francisco, CA 94118, USA) 73-A, 612 (1991)

Current concepts review. The role of ultrasound in the diagnosis and management of congenital dislocation and dysplasia of the hip. Harcke, H.Th., Kumar, S.J. (Alfred I. du Pont Inst., P.O. Box 269, 1600 Rockland Road, Wilmington, Delaware 19899, USA) 73-A, 622 (1991)

\section{Journal of Computer Assisted Tomography (Bethesda)}

High dose chloral hydrate sedation for children undergoing CT. Greenberg, S.B. et al. (Dept. of Rad., St. Christopher's Hosp. for Children, Front at Erie St., Philadelphia, PA 19134-1095, USA) 15, 467 (1991)

\section{Journal of Neurosurgery (Rochester)}

Intracranial germ-cell tumors in children. Hoffman, H.J. et al. (Div. of Neurosurg, The Hosp. for Sick Children, 555 Univ. Ave., Toronto, Ontario M5G 1X8, Canada) 74, 545 (1991)

Familial occurrence of arteriovenous malformation of the brain. Yokoyama, K. et al. (Dept of Neurosurg., Takayama Red Cross Hosp., 3-11, Tenmancho, Takayama-Shi, Gifu-Ken 506, Japan) 74, 585 (1991)

Fusiform dilatations of the carotid artery following radical surgery of childhood craniopharyngiomas. Sutton, L.N. et al. (Surgical Associates of the Children's Hosp. of Philadelphia, One Children's Center, 34th St. and Civic Center BIvd., Philadelphia, PA 19104-4399, USA) 74, 695 (1991)

Benign intrinsic tectal "tumors" in children. May, P.L. et al. (H.J.Hoffman, Div. of Neurosurg., The Hosp. for Sick Children, 555 Univ. Ave., Toronto, Ontario, M5G 1X8, Canada) 74, 867 (1991)

\section{Journal of Nuclear Medicine (New York)}

Radioimmundetection of neuroblastoma with iodine-131-3F8: Correlation with biopsy, iodine-131-metaiodobenzylguanidine and standard diagnostic modalities. Yeh, S.D. J. et al. (Dept. of Med. Imaging, 1275 York Ave., New York, NY 10021, USA) 32, 769 (1991)

Glomerular filtration rate in children: Where we have been? Where we are going? Shore, R. M. (The Children's Mem. Hosp., Chicago, Il, USA) 32, $1297(1991)$

\section{Journal of Pediatrics (St. Louis)}

Role of chlamydia pneumoniae in acute chest syndrome of sickle cell disease. Miller, S. T. et al. (Dept. of Ped., State Univ. of New York, Health Sci. Center at Brookiyn, Box 49, 450 Clarkson Ave., Brooklyn, NY 11203, USA) 118, $30(1991)$
Asymmetric growth of the lateral cerebral ventricle in infant with posthemor rhagic ventricular dilation. Brann, B. S., IV, et al. (Dept. of Ped.. Children's Hosp. of New Mexico, Univ. of New Mexico Sch. of Med., 2211 Lomas Blvd., Albuquerque, NM 87131, USA) 118, 108 (1991)

Persistent crying in infancy as a presentation of Chiari type I malformation. Listernick, R., Tomita, T. (Dept. of Ped., Northwestern Univ. Med. Sch. Div. of General Acad. and Emergency Ped., Children's Mem. Hosp., 2300 Children's Plaza, Chicago, IL 60614, USA) 118, 567 (1991)

\section{Journal of Pediatric Surgery (New York)}

Distal congenital esophageal stenosis associated with esophageal atresia. Neilson, I. R. et al. (Guttman, F. M., Ped. General Surg., Children's Hosp., 2300 Tupper, Montreal, Quebec H3H 1P3, Canada) 26, 478 (1991)

Biliary atresia and the polysplenia syndrome. Karrer, E.M. et al. (Children's Health Center, 1950 Ogden St, B323, Denver, CO 80218, USA) 26, 524 (1991)

Experience with bilateral renal artery stenosis as a cause of hypertension in childhood. Guzzetta, Ph.C. et al. (Dept. of Ped. Surg., Children's National Med. Center, 111 Michigan Ave NW, Washington, DC 20010, USA) 26, 532 (1991)

Magnetic resonance imaging for localizing the nonpalpable undescended testis. Miyano, T. et al. (Dept. of Ped. Surg., Juntendo Univ. Sch. of Med., 2-11 Hongo, Bunkyoku, Tokyo 113, Japan) 26, 607 (1991)

Diagnosis of H-type tracheoesophageal fistula. Benjamin, B., Pham, T. (FRACS, FAAP, 231 Macquarie St, Sydney, New South Wales 2000, Australia) 26,667 (1991)

Acquired tracheoesophageal fistula in infancy and childhood. Szold, A. et al. (Dept. of Ped. Surg., Hadassah Univ. Hosp. Mount Scopus, POB 24035, Jerusalem, Israel) 26, 672 (1991)

Failure of duplex sonography to diagnose hepatic artery thrombosis in a highrisk group of pediatric liver transplant recipients. McDiarmid, S. V. et al. (R. W. Busuttil, UCLA Dept. of Surg., Room 77-132 CHS, 10833 Le Conte Ave, Los Angeles, CA 90024 , USA) 26, 710 (1991)

Giant hemangioma of the arm associated with cardiac failure and the Kasabach-Merritt syndrome in a neonate. Currie, B. G. et al. (FRACS, Dept. of Paed. Surg., Prince of Wales Children's Hosp., Randwick, NSW 2031, Australia) 26,734 (1991)

Primary lesser saphenous vein aneurysm in a child. Ramadan, F., Johnson, G. Jr. (Div. of Vascular Surg., Univ, of North Carolina Sch. of Med., 210 Burnett-Womack, Campus Box 7210, Chapel Hill., NC 27599-7210, USA) 26, $738(1991)$

Journal of Urology (Toronto)

The detection of reflux nephropathy in infants by ${ }^{99}$ technetium dimercaptosuccinic acid studies. Farnsworth, R. H. et al. (Dept. of Urol., The Prince Henry Hosp., Sydney, Australia) 145, 542 (1991) 
15. Laughlin CL, Loe GL (1982) The prominent falx cerebri: new ultrasonic observation in hypophosphatasia. J Clin Ultrasound 10:37

16. Kousseff BG, Mulivor RA (1981) Prenatal diagnosis of hypophosphatasia. Obstet Gynecol 57: 98

17. Novelli G, Mennello F, Cosmi EV, Biagioni S, Dallapiccola B (1987) Alkaline phosphatase expression in human chorionic villi. Exp Cell Biol 55: 34

18. Ornoy A, Adomian GE, Rimoin DL (1985) Histologic and ultrastructural studies on the mineralization process in hypophosphatasia. Am J Med Genet 22: 743

19. Oestreich AE, Bofinger MK (1989) Prominent transverse (Bowdler) bone spurs as a diagnostic clue in a case of neonatal hypophosphatasia without metaphyseal irregularity. Pediatr Radiol 19:341

20. Bader PI, Lewis W (1988) Clinical spectrum of infantile hypophosphatasia within a single family. Proc Greenwood Genetic Center 7: 199

R. S. Lachman, M.D. International Skeletal Dysplasia Registry Cedars-Sinai Medical Center 444 S. San Vicente Blvd. Suite 1001

Los Angeles, CA 90048

USA

\section{Literature in pediatric radiology (continued from p. 420)}

Medical and Pediatric Oncology (New York)

Proceedings of the Brazilian Wilms' Tumor Cooperative Group Review, Committee, Sao Paulo, Brazil

Partial nephrectomy for bilateral Wilms' tumor. Alfer, W. Jr. et al. (G.J. D'Angio, Dept. of Rad. Oncol., Hosp. of the Univ. of Pennsylvania, 3400 Spruce St., Philadelphia, PA, USA) 19, 131 (1991)

Pancreatoblastoma: Response to chemotherapy. Vannier, J.-P. (Ped., Hôp. Charles Nicolle, 1 rue de Germont, 76031 Rouen. France) 19, 187 (1991)

Pediatric Clinics of North America (Philadelphia)

Evaluation of the child with a suspected malignant solid tumor. Fletcher, B.D., Pratt, Ch. B. (St. Jude Children's Res. Hosp. and Univ. of Tennessee Coll. of Med., Memphis, TN, USA) 38, 223 (1991)

Osteosarcoma: Clinical features and evolving surgical and chemotherapeutic strategies. Meyer, W.H., Malawer, M.M. (Dept. of Hematol.-Oncol, St.Jude Children's Res. Hosp., Univ. of Tennessee Coll. of Med., Memphis, TN, USA) 38, 317 (1991)

Ewing's sarcoma: Radiotherapy versus surgery for local control. Horowitz, M.E. et al. (Ped. Branch, National Cancer Inst., Bethesda, MD, USA) 38, 365 (1991)

Pediatrics (Elk Grove Village)

Primary vesicoureteral reflux in the black child. Steven, L. TC. et al. (Dept. of Ped. Urol., 111 Michigan Ave. NW, Washington, DC 20010, USA) 87, 538 (1991)

Acute lobar nephronia: A review. Rathore, M.H. et al. (Div. of Infectious Diseases and Dept of Rad., St. Louis Univ. Sch. of Med., Cardinal Glennon Children's Hosp., St. Louis, MO, USA) 87, 728 (1991)

Pollakisuria, extraordinary daytime urinary frequency: Experience in a pediatric practice. Bass, L. W. (Univ. of Pittsburgh Sch. of Med, Pittsburgh, PA 15213, USA) 87, 735 (1991)

\section{Radiologic Clinies of North America (Philadelphia)}

Radiographic manifestations of anomalies of the brain. Sato, Y. et al. (Dept. of Rad., Univ. of Iowa Coll. of Med., Iowa City, IA, USA) 29, 179 (1991)

Radiographic manifestations of congenital anomalies of the skull. Kaplan, S. B. et al. (Dept. of Rad., Presbyterian-Univ. Hosp., Pittsburgh, PA, USA) 29, 195 (1991)

Radiographic manifestations of congenital anomalies affecting the airway. Carpenter, B. L. M., Merten, D. (Dept. of Diagn. Rad., Univ. of Minnesota Hosp. and Clin. Minneapolis, MN, USA) 29, 219 (1991)

Bronchopulmonary and neurenteric forms of foregut anomalies. Imaging for diagnosis and management. Haddon, M. J., Bowen, A'D (Dept. of Rad. Oregon Health Serv. Univ., Portland, OR, USA) 29, 241 (1991)

Radiographic manifestations of anomalies of the lung. Keslar, P. et al. (Dept. of Rad., Univ. of Florida, Gainesville, FL, USA) 29, 255 (1991)

Radiographic manifestations of anomalies of the chest wall. Swischuk, L.E., Stansberry, S. D. (Dept. of Rad., The Univ. of Texas Med. Branch, Child Health Center, Galveston, TX, USA) 29, 271 (1991)

Magnetic resonance imaging of congenital heart disease in the pediatric patient. Bisset, G. S. III (Rad. and Ped., Children's Hosp. Med. Center, Univ. of Cincinnati Coll. of Med., Cincinnati, OH, USA) 29, 279 (1991)

Radiographic manifestations of congenital anomalies of the aortic arch. Jaffe, R. B. (Rad. and Ped., Primary Children's Med. Center, Ped. Med. Imaging Dept., Salt Lake City, UT, USA) 29, 319 (1991)

Radiographic manifestations of anomalies of the gastrointestinal tract. Bender, Th.M. et al. (Dept. of Rad., Univ. of Pittsburgh Sch. of Med., Pittsburgh, PA, USA) 29, 335 (1991)
Radiographic manifestations of renal anomalies. Daneman, A., Alton, D.J. (Dept. of Rad., Univ. of Toronto, Hosp. for Sick Children, Toronto, Ontario, Canada) 29,351 (1991)

Radiographic manifestations of congenital anomalies of the lower urinary tract. Herman. Th.E., McAlister, W.H. (Mallinckrodt Inst. of Rad., Washington Univ. Sch. of Med., St. Louis, MS, USA) 29, 365 (1991)

Radiographic manifestations of anomalies of the limbs. Ledesma-Medina, J. et al. (Dept. of Rad., Univ. of Pittsburgh Sch. of Med., Pittsburgh, PA, USA) 29,383 (1991)

Radiographic manifestations of congenital anomalies of the spine. O'Connor, J.F. et al. (Dept. of Rad., Ped. and Anatomy, Boston Univ. Sch. of Med., Boston, MA, USA) 29, 407 (1991)

Contemporary imaging approach to pediatric urologic problems. Berdon, W.E. (Dept. of Rad., Columbia Univ. Coll. of Physicians and Surg., New York, NY, USA) 29, 605 (1991)

Radiologic Technology (Albuquerque)

Percutaneous feeding tube method for use in children. Long, B. et al. (Radiol. Sci. Program, Indiana Univ. Sch. of Med,,541 Clin. Drive 922, Indianapolis, IN 46202-5111, USA) 62, 274 (1991)

Radiology (Easton PA)

Antropyloric muscle thickness at US in infants: what is normal? O'Keeffe, F. N. et al. (Swischuk, L. E., Dept. of Rad., Univ. Med. Branch, 301 Univ. Blvd., Galveston, TX 77550, USA) 178, 827 (1991)

Lesions that manifest as medial cheek and nasolabial fold masses. Som, P.M., Norton, K.I. (Dept. of Rad., Box 1234, Mount Sinai Med. Center, 1 Gustave L. Levi PL, New York, NY 10029-6574, USA) 178, 831 (1991)

Nerve root avulsion of birth palsy: comparison of myelography with CT myelography and somatosensory evoked potential. Hashimoto, T. et al. (Dept. of Rad., Research Inst. for Microbial Diseases, Univ., 3-1 Yamadaoka Suita, Osaka, 565, Japan) 178, 841 (1991)

Use of oximetry during MR imaging of pediatric patients. Fisher, D.M., Litt, L. (Dept. of Anesthesia, Ped., Univ., San Francisco, CA 94143-0648, USA) 178, $891(1991)$

Obstructed uterovaginal anomalies: demonstration with sonography. Part I. Neonates and Infants. Nussbaum Blask, A. R. et al. (Dept. of Rad., Children's Hosp. Nat. Med. Center, 111 Michigan Av., Washington, DC 20010, USA) 179,79 (1991)

Obstructed uterovaginal anomalies: demonstration with sonography. Part II. Teenagers. Nussbaum Blask, A. R. et al. (Dept. of Rad., Children's Hosp, Nat. Med. Center, 111 Michigan Av. NW, Washington, DC 20010, USA) 179, 84 (1991)

Legg-Calvé-Perthes disease: imaging with MR. Egund, N., Wingstrand, H. (Dept. of Rad., Univ. Hosp., DK-5000 Odense, Denmark) 179, 89 (1991)

The toddler's cuboid fracture. Blumberg, K., Patterson, R. J. (Dept. of Rad. Children's Med. Center, 2525 Chicago Av. S., Minneapolis, MN 55404, USA) 179,93 (1991)

Assessment of brain death in children by means of P-31 MR spectroscopy: preliminary note. Work in progress. Kato, T. et al. (Dept. of Ped., Kameda General Hosp., 929 Higashi-cho, Kamogawa City, Chiba 296, Japan) 179, $95(1991)$

Postpneumonectomy syndrome after left lung resection. Quillin, S.P., Shackelford, G.D. (Shackelford, G.D., Mallinckrodt Inst. of Rad., Washington Univ. School of Med., 510 S Kingshighway Blyd., St.Louis, MO 63110, USA) 179, 100 (1991) 
2. Kuroki Y, Suzuki Y, Chyo H, Hata A, Matsui I (1981) A new malformation syndrome of long palpebral fissures, large cars, depressed nasal tip, and skeletal anomalies associated with postnatal dwarfism and mental retardation. J Pediatr 99:570

3. Niikawa N, Kuroki Y, Kajii T (1982) The dermatoglyphic pattern of the Kabuki make-up syndrome. Clin Genet 21:315

4. Taybi H, Lachman RS (1990) Radiology of Syndromes, Metabolic Disorders, and Skeletal Dysplasias. Year Book Medical Publishers, Chicago

5. Kuroki Y, Katsumata N, Eguchi T, Fukushima Y, Suwa S, Kajii T (1987) Precocious puberty in Kabuki make-up syndrome. J Pediatr 110: 750

6. Ohdo S, Madokoro H, Sonoda T, Nishiguchi T, Kawaguchi K, Hayakawa K (1985) Kabuki make-up syndrome (Niikawa-Kuroki syndrome) associated with congenital heart disease. J Med Genet 22: 126

7. Niikawa N, Kuroki Y, Kajii T, Matsuura N, Ishikiriyama S, Tonoki H, Ishikawa N, Yamada Y, Fujita M, Umemoto H, Iwama Y, Kondoh I et al. (1988) Kabuki make-up (Niikawa-Kuroki) syndrome: a study of 62 patients. Am J Med Genet 31: 565

8. Braun OH, Schmidt E (1984) Kabuki make-up syndrome (Niikawa-Kuroki syndrome) in Europe (letter). J Pediatr 105: 849

9. Gillis R, Klar A, Gross-Kieselstein E (1990) The Niikawa-Kuroki (Kabuki make-up) syndrome in a Moslen Arab child. Clin Genet 38:378
10. Koutras Y, Fisher S (1982) Niikawa-Kuroki syndrome: a new malformation syndrome of postnatal dwarfism, mental retardation, unusual face, and protruding ears. J Pediatr 101: 750

11. Pagon RA, Downing AL, Ruvalcaba RHA (1986) Kabuki makeup syndrome in a Caucasian. Ophthalmol Pediatr 7:97

12. Sheikh TM, Qazi QH, Beller E (1986) Nikawa-Kuroki syndrome (Kabuki make-up syndrome) in a Hispanic child (abstract). Pediatr Res 20:340A

13. Halal F, Gledhill R, Dudkiewicz A (1989) Autosomal dominant inheritance of the Kabuki make-up (Nikawa-Kuroki) syndrome. Am J Med Genet 33: 376

14. Kaiser-Kupfer MI, Mulvihill JJ, Klein KL, Parry DM, Schlesinger SL (1986) The Niikawa-Kuroki (Kabuki make-up) syndrome in an American black. Am J Ophthalm 15: 667

15. McKusick VA (1990) Mendelian inheritance in man. Catalog of autosomal dominant, autosomal recessive, and X-linked phenotipes. J Hopkins University Press, Baltimore

\section{Dr. L. Giuffrè}

Istituto Materno Infantile

Universita Degli Studi di Palermo

Via Cardinale Rampolla 1

I-90142 Palermo

Italy
Literature in pediatric radiology (continued from $p .427$ )

Linear areas of echogenicity in the thalami and basal ganglia of neonates: an expanded association. Work in progress. Hughes, P. et al. (Weinberger, E., Dept. of Rad., Univ. of Washington School of Med., 4800 Sand Point Way NE, Seattle, WA 98105, USA) 179, 103 (1991)

Pediatric musculoskeletal MR imaging. Moore, S. G. et al. (Dept. of Diagn. Rad., S-058, Stanford Univ. Sch. of Med. Stanford, CA 94305, USA) 179, 345 (1991)

True hermaphroditism: Sonographic demonstration of ovotestes. Eberenz, W. et al. (Dept. of Urol., Riley Hosp. for Children, Indianapolis, IN, USA) 179, 429 (1991)

Midgut volvulus in infants: Diagnosis with US. Work in progress. Leonidas, J.C. et al. (Dept. of Rad. of the Schneider Children's Hosp., Long Island Jewish Med. Center, New Hyde Park, NY 11042, USA) 179, 491 (1991)

Crohn disease in the pediatric patient: CT evaluation. Jabra, A. A. et al. (Dept. of Rad, and Radiol. Sci., The Johns Hopkins Med. Inst., $600 \mathrm{~N}$ Wolfe St., Baltimore, MD 21205, USA) 179, 495 (1991)

Chondromyxoid fibroma: Radiographic appearance in 38 cases and a review of the literature. Wilson, A.J. et al. (Mallinckrodt Inst. of Rad., Washington Univ. Sch. of Med., 510 S. Kingshighway Blvd., St. Louis, MO 63110, USA) 179, $513(1991)$

Pediatric gynecologic sonography. Siegel, M.J. (Mallinckrodt Inst. of Rad., Washington Univ. Sch. of Med., 510 S Kingshighway Blvd., St. Louis, MO 63110, USA) 179,593 (1991)

Normal pituitary gland: Changes in shape, size, and signal intensity during the 1st year of life at MR imaging. Cox, T.D., Elster, A.D. (Dept. of Rad., Wake Forest Univ., Bowman Gray Sch. of Med., 300 S Hawthorne Rd, Winston-Salem, NC 27103, USA) 179,721 (1991)

Subperiosteal abscess in children: Scintigraphic appearance. Allwright, St.J. et al. (J.H.Miller, Div. of Nuclear Rad. and Diagnostic Rad., Childrens Hosp. Los Angeles, 4650 Sunset Blvd., Los Angeles, CA 90027 , USA) 179, 725 (1991)

Osteomyelitis in children with sickle cell disease: Early diagnosis with contrast-enhanced CT. Stark, J.E. et al. (C. M. Glasier, Dept. of Rad., Univ. of Arkansas for Med. Sci. and Arkansas Children's Hosp., 800 Marshall St, Little Rock, AR 72202, USA) 179, 731 (1991)

Bone mass in healthy children: Measurement with quantitative DXA. ${ }^{1}$. Southard, R.N. et al. (J.D.Morris, Dept. of Ped.-Rad., Columbus Children's Med. Hosp., Ohio State Univ., 700 Children's dr, Columbus, OH 43205, USA) 179,735 (1991)

Mesenteric vascular anatomy at CT: Normal and abnormal appearances. Zerin, J. M., DiPietro, M. A. (Dept. of Rad., Sect. of Ped.-Rad., Univ. of Michigan Hosp., 1500 E Med. Center Dr, Ann Arbor, MI 48109-0252, USA) 179, 739 (1991)

Pulmonary blastoma: A rare childhood malignancy. Senac, M. O., Jr. et al. (Dept. of Rad. and Pathol., Children's Hosp. Los Angeles, 4650 Sunset Blvd, Los Angeles, CA 90027 , USA) 179, 743 (1991)
Cystic fibrosis: Scoring system with thin-section $\mathrm{CT}^{\mathrm{l}}$. Bhalla, M. et al. (Dept. of Rad. and Ped., Med. Univ. of South Carolina, 171 Ashley Ave., Charleston, SC29425, USA) 179, 783 (1991)

Meningioangiomatosis: Clinical, radiologic, and histopathologic correlation. Aizpuru, R. N. et al. (Dept. of Rad., Univ. of Minnesota Sch. of Med., Minneapolis, MN, USA, R.M. Quencer) 179,819 (1991)

\section{Archives of Disease in Childhood (London)}

Computed tomography of the brain in kwashiorkor: a follow up study. Househam, K.C. (Dept. of Paed. and Child Health, Fac. of Med., Univ. of the Orange Free State, P. O. Box 339 (G69), Bloemfontein 9300, South Africa) 66, 623 (1991)

Imaging in influenza A encephalitis. Protheroe, S. M., Mellor, D. H. (Dept. of Paed., Peterborough District Hosp., Thorpe Road, Peterborough PE3 6DA, England) 66, 702 (1991)

Intussusception in cystic fibrosis. Holmes, M. et al. (7 Pembroke St., Dublin 4 , Ireland) 66, 726 (1991)

Clinical Radiology (London)

Wilms' tumour: Pre- and post-chemotherapy CT appearances. Ng, Y.Y. et al. (Dept. of Rad., Hosp. for Sick Children, Great Ormond St., London. WC1N3JH, England) 43, 255 (1991)

The empty rectum on plain $X$-ray. Does it have any significance in the neonate? Bradley, M. J., Pilling, D. (Univ. Dept. of Rad., Royal Liverpool Hosp., Prescot St., Liverpool. England) 43, 265 (1991)

The right aortic arch revisited. Glew, D., Hartnell, G. G. (Dept. of Rad., Bristol Royal Infirmary, Marlborough St., Bristol BS2 8HW, England) 43, 305 (1991)

Case report: The ultrasound and computed tomography appearance of mesenteric Castle-man disease. Garber, S.J., Shaw, D.G. (Dept. of Rad., The Hosp. for Sick Children, Great Ormond St., London WC1, England) 43,429(1991)

Journal of Bone and Joint Surgery (London)

The acetabular rim syndrome. A clinical presentation of dysplasia of the hip. Klaue, K. et al. (Clin. Res. Fellow, Dept. of Orthopaed. Surg., Inselspital, CH-3010 Bern, Switzerland) 73-B, 423 (1991)

Annales de Pédiatrie (Paris)

Recurrent multifocal periostosis of childhood. Report of a familial case. Ben Becher, S. et al. (Serv. de Péd., Urgences et Consultations externes, Hôp. d'Enfants Tunis Jebbari, 1006 Tunis, Tunesia) 38, 345 (1991)

Biballism. Report of a clinical pediatric case. Boukthir, S. et al. (Hôp. d'Enfants, Bab Saadoun, 1007 Tunis, Jebbari, Tunesia) 38, 358 (1991)

Annales de Radiologie (Paris)

Radiological anatomy of the ethmoid bone. Guirado, C.R. (Inst. de Tomodensitometria, Muntaner, 239, Entlo A 08021 Barcelona, Spain) 34, 9 (1991) 
tern, marked edema and prominent mass effect and especially the "ringlike" peripheral pattern of enhancement. This peripheral rim was reported in only two previous cases of brain lymphoma of adult patients, one of them with AIDS [4,9].

In conclusion, in childhood primary brain lymphoma is extremely rare [11, 12]. Our case presented atypical CT features, mimicking gliomas, or inflammatory disease, especially brain abscess. Despite its rarity brain lymphoma should be included in the differential diagnosis, even in the presence of unusual CT features.

\section{References}

1. Weingarten K, Zimmerman RD (1986) CT of intracranial lymphoma. Semin US CT MR 7:9

2. Schwaighofer BW, Hesselink JR, Press GA, Wolf RL, Healy ME, Berthoty DP
(1989) Primary intracranial CNS lymphoma:MR manifestations. AJNR 10:725

3. Palacios E, Gorelick PB, Gonzales CV, Fine M (1982) Malignant lymphoma of the nervous system. $\mathbf{J}$ Comput Assist Tomogr 6: 689

4. Lee YY, Bruner JM, Van Tasse P, Libshitz H (1986) Primary central nervous system lymphoma: CT and pathologic correlation. AJNR 7:599

5. Jack CR, O'Neill BP, Banks PM, Reese DF (1988) Central nervous system lymphoma: histologic types and CT appearance. Radiology 167:211

6. Vakili ST, Muller J, Shidnia H, Campbell RL (1986) Primary lymphoma of the central nervous system: a clinicopathologic analysis of 26 cases. J Surg Oncol 33: 95

7. Kawakawimi Y, Kazuo T, Rinkichi O, Asari S, Akira N (1985) Primary central nervous system lymphoma. J Neurosurg 6:522

8. Helle TL, Brill RA, Colby TV (1984) Primary lymphoma of the central nervous system. Clinicopathological study of experience at Stanford. J Neurosurg 60:94

9. Mendenhall NP, Thar TL, Agee OF, Harty-Golder B, Ballinger WE, Million
RR (1982) Primary lymphoma of the central nervous system. Computerized tomography scan characteristics and treatment results for 12 cases. Cancer 52 : 1993

10. Yang PJ, Knake JE, Gabrielsen TO, Latack JT, Gebarsky SS, Metha BA, Metes JJ (1985) Primary and secondary histiocyticlymphoma of the brain: CT features. Radiology 154:683

11. Berry DH, Glaster ES, Jimerez JF, Grunow WA, Jordan R (1985) Primary intracranial immunoblastic lymphoma in infancy. Am J Pediatr Hematol Oncol 7:141

12. Tadmor R, Harwood-Nassh DE, ScottiG, Savoiardo M, Musgrave MA, Fitz CR, Chung S, Modan M (1982) Intracranial neoplasms in children: the effects of computed tomography on age distribution. Radiology 145: 371

H. Schulman, M.D.

Department of Radiology

Soroka Medical Center

P. O. Box 151

Beer-Sheva 84101

Israel

\section{Literature in pediatric radiology (continued from p. 431)}

\section{Archives Françaises de Pédiatrie (Paris)}

Le syndrome de Budd-Chiari chez l'enfant. A propos de 7 observations. Boudhina, T. et al. (Serv. de Péd., Urgences et Consultations, Hôp. d'Enfants. Tunis, Tunesia) 48,243 (1991)

Ganglioneurome lombaire en sablier (Cas radiologique du mois). Adrien, C. et al. (Serv. de Rad., Hôp. Trousseau, 26, av. du Arnold-Netter, F-75012 Paris, France) 48, 275 (1991)

Un cas de leucoencéphalopathie après injection intraventriculaire de méthotrexate (Cas radiologique du mois). Krief, S. et al. (Serv. de Rad. et de I'Unité d'Hématol. et d'Oncol. Péd., Hôp. Trousseau, 26, av. du Dr A.-Netter, F-75012 Paris, France) 48, 277 (1991)

Cas radiologique du mois: Rubrique iconographique. Pasquier, J.M. et al. (L'Hôp. Debrousse, 29, rue Soeur-Bouvier, F-69322 Lyon, France) 48, 353 (1991)

Rechute orbitaire et musculaire d'un lymphome de Burkitt. Bergeron, C. et al. (L'Unité d'Hematol. Oncol.-Péd., CHRU Rennes, BP 56129, F-35056 Rennes, France) 48,415 (1991)

Tératome du nasopharynx du nouveauné (Cas radiologique du mois). Panuel, M. et al. (Serv. de Rad.-Péd., de la Clin. Chir. Infantile, Dépt. d Anesth.Réanim.-Péd., CHU Timone, F-13385 Marseille, France) 48, 427 (1991)

Jonrnal de Radiologie (Paris)

Fatty liver infiltration of the children related to obesity. Coche, G. et al. (Serv. de Rad., Clin. du Mail, 47-49, Mail Albert $1^{\text {er }}$, F-80000 Amiens, France) 72, $235(1991)$

\section{Aktuelle Radiologie (Stuttgart)}

Genetic injury from radiation and other environmental factors. Henschler, D. (Inst. f. Toxikologie der Univ., Versbacher Str.9, W-8700 Würzburg, FRG) 1, 116(1991)

\section{American Journal of Perinatology (Stuttgart)}

Neonatal hypertension and thrombosis of the ductus arteriosus. Morisot, C. et al. (P.Lequien, Serv. de Péd. Néonatale Calmette Hosp., F-59037 Lille, France) 8,77 (1991)

Prenatal sonographic diagnosis of lipoma of the corpus callosum in a fetus with Goldenhar syndrome.Jeant, Ph. etal.(Dept. of Rad. Vanderbilt Univ. Med. Center, 21st St. and Garland, Nashville, TN 37232-2675, USA) 8, 89 (1991)

Radiographic findings associated with surfactant treatment. Soll, R.F et a]. (Dept. of Ped., Univ. of Vermont Coll. of Med., A 121 Given Bldg., Burlington, VT 05405, USA) 8, 114 (1991)

Prenatal diagnosis of fetal cephalocele: A sonographic spectrum. Jeanty, Ph. et al. (Dept. of Rad., Vanderbilt Univ. Med. Center, 21st St. and Garłand Nashville, TN 37232-2675, USA) 8, 144 (1991)
Imaging case of the month: Potter's syndrome. McGravey, V. J., Ghoreishi, S. (Div. of Neonatology, Mercy Hosp., 565 Abbott Road, Buffalo, NY 14220, USA) 8, 153 (1991)

Fetal periventricular hemorrhage in von Willebrand's disease: Short review and first case presentation. Mullaart, R. A. et al. (Interdisciplinair Kinderneurol. Centrum, Radboudziekenhuis, PO Box 9101, 6500 HB Nijmegen, Netherlands) 8, 190 (1991)

Congenital mesoblastic nephroma, hemorrhagic shock, and disseminated intravascular coagulation in a newborn infant. Zach, T. L. et al. (R. F. Cifuentes, Dept. of Ped., Div. of Neonatol., Hennepin County Med. Center, 701 Park Ave. South, Minneapolis, MN 55415, USA) 8,203 (1991)

Pleural effusion in aneuploidy. Petrikovsky, B. M. et al. (Maternal and Fetal Med., State Univ. of New York at Stony Brook, Stony Brook., NY 117948091, USA) 8,214 (1991)

Pitfall in the diagnosis of nuchal cystic hygroma. Tigges, St. et al. (Ph.Jeanty, Vanderbilt Univ. Med. Center. Dept. of Rad., 21st St and Garland, Nashville, TN 37232-2675, USA) 8, 217 (1991)

Archives of Orthopaedic and Trauma Surgery (Berlin)

Juvenile and idiopathic kyphosis. Long-term follow-up of 20 cases. Farsetti. P. et al. (Piazza Ruggero di Sicilia, 1, I-00162 Rome, Italy) 110, 165 (1991)

European Journal of Nuclear Medicine (Berlin)

Dosimetry of swallowed non-absorbed technetium $99 \mathrm{~m}$ radiopharmaceuticals in paediatric patients. Watson, E. E. (Radiopharmaceutical Internal Dose Information Center, Med. Sci. Div., Oak Ridge Associated Univ., Oak Ridge, TN 37831-0117, USA) 18,288 (1991)

Dosimetry in paediatrics. Wynchank, S. (Res. Inst. of Med. Biophysics, Med. Res. Council, P.O. Box 70, Tygerberg, South Africa) 18,290 (1991)

Dosimetry of iodine 131 metaiodobenzylguanidine for treatment of resistant neuroblastoma: results of a UK study. Fielding, S. L. et al. (Med. Physics Dept., St.Lukes Hosp., Guildford, Surrey GU13NT,England) 18,308(1991)

European Journal of Pediatrics (Berlin)

Control of proven pulmonary and suspected CNS aspergillus infection with itraconazole in a patient with chronic granulomatous disease. Kloß, S. et al. (V.Wahn, Children's Hosp., ENT Hosp., Heinrich-Heine Univ. Düsseldorf, Moorenstr. 5, W-4000 Düsseldorf, FRG) 150, 483 (1991)

Medullary sponge kidneys and unilateral Wilms tumour in a child with Beckwith-Wiedemann syndrome. Beetz, R. et al. (Dept. ofPaed. and Urol., Univ. Hosp. Langenbeckstr. 1, W-6500 Mainz 1,FRG) 150,489(1991)

Significance of ultrasound appearances in the neurological development and cognitive abilities of preterm infants at 5 years. Fawer, C.L., Calama, A. (Neonatal and Developmental Units, Dept. of Paed., C.H.U.V., CH-1011 Lausanne, Switzerland) 150,515 (1991) 
this high-risk group, Copel et al claim the four-chamberview has a positive predictive value of $95.8 \%$ and a negative predictive value of $99.4 \%$ [2]. Diagnosis of HLHS with $100 \%$ accuracy at 18-24 weeks gestation is accepted as the rule [1-5], although two atypical cases of HLHS have been described $[4,5]$ in which a left ventricle of initially normal size but poor contractility was noted during detailed fetal echocardiography.

Despite the high yield of fetal echocardiography in the high-risk group, most cases of major congenital heart disease will be found in the low-risk population group (2-3 per thousand). The fourchamber cardiac view, a standard part of the routine obstetric ultrasound examination $[2,3]$, is said to exclude most severe congenital heart disease (HLHS, atresia of the mitral, pulmonary or tricuspid valves, double inlet ventricle, atrioventricular canal defect) [2, 3], from 16 weeks gestation onwards. It has come to be expected that any competent obstetric ultrasound examination will detect HLHS and most (but not all) other severe congenital heart anomalies from 16 weeks gestation onwards, using the four-chamber view alone. If cine-loop technology is not available, it is difficult at times to obtain an ideal four-chamber view on hard copy during a routine timelimited obstetric ultrasound examination, and some reliance is made inevitably on the real-time appearance seen by the sonographer.

The etiology of HLHS is unknown. The development of classical HLHS following less typical appearances in the second trimester in our case and the two atypical cases previously reported $[4,5]$ may indicate that the final expression of HLHS has a variable age of onset.

In the light of our case, we believe the following points can be made. HLHS cannot be confidently excluded by a normal four-chamber view in the second trimester. The accuracy of the four-chamber view in "routine" antenatal ultrasound is not well established, although the four-chamber view is reliable in diagnosing major congenital heart disease when it forms part of a detailed fetal echocardiographic examination. It is important for the sonographer to note function as well as structure when obtaining the four-chamber view.
Acknowledgement. We thank Dr. R.Chisholm for technical advice.

\section{References}

1. Allan LD, Chita SK, Sharland GJ, Fagg NLK, Anderson RH, Crawford DC (1989) The accuracy of fetal echocardiography in the diagnosis of congenital heart disease. Int J Cardiol 25: 279

2. Copel JA, Pilu G, Green J, Hobbins JC, Kleinman CS (1987) Fetal echocardiographic screening for congenital heart disease: the importance of the four-chamber view. Am J Obstet Gynecol 157: 648

3. Allan LD, Crawford DC, Chita SK, Tynan MJ (1986) Prenatal screening for congenital heart disease. Br Med J 292: 1717

4. Vincent RN, Menticogou S, Chanas D, Manning F, Collins GF, Smallhorn J (1987) Prenatal diagnosis of an unusual form of hypoplastic left heart syndrome. J Ultrasound Med 6:261

5. Allan LD, Sharland G, Tynan MJ (1989) The natural history of the hypoplastic left heart syndrome. Int $J$ Cardiol 25:341

Dr. N.G. Anderson

Department of Radiology

Christchurch Hospital

Christchurch

New Zealand

\section{Literature in pediatric radiology (continued from $p .435$ )}

Moebius syndrome with central hypoventilation and brainstem calcification: a case report. Fujita, I. et al. (Dept. of Paed., Fac. of Med., Kyushu Univ., 3-1-1 Mai-dashi, Higashiku, Fukuoka 812, Japan) 150,582 (1991)

Intracranial calcifications and nephrogenic diabetes insipidius. Rocco, M. Di et al. (Second Paed. Div., G. Gaslini Inst., I-16148 Genova, Italy) 150, 599 (1991)

Magnetic resonance imaging in idiopathic hypopituitarism. Doraiswamy, P.M. et al. (Duke Univ. Med. Center, Durham NC27710, USA) 150,600 (1991)

European Journal of Pediatric Surgery (Stuttgart)

Midline dermal sinuses and cysts and their relationship to the central nervous system. Peter, J.C. et al. (Dept. of Ped.-Neurosurg.. Inst. of Child Health, Red Cross War Memorial Children's Hosp., Rondebosch 7700, Cape Town, South Africa) 1,73 (1991)

Acute multilocular osteomyelitis in infancy and childhood. Sichardt, G. et al. (Klin. und Poliklin. f. Kinderchir. der Johannes Gutenberg-Univ. Mainz, Langenbeckstr.1, W-6500 Mainz,FRG) 1, 102 (1991)

Neonatal primary hyperparathyroidism - A case report and review of the literature. Blair, J. W., Carachi, R. (Royal Hosp. for Sick Children, Yorkhill, Glasgow, England) 1,110(1991)

Intussusception: effectiveness of gas enema. Glover, J.M. et al. (S. W. Beasley, Paed.-Surg. Dept. of Surg., Royal Children's Hosp., Flemington Road, Parkville 3052, Australia) 6, 195 (1991)

Anteriorly displaced anus: an under-recognized cause of Chronic constipation. Ishitani, M. B. et al. (Dept. of Surg., Box 181 Children's Med. Center, Univ. of Virginia Health Sci.Center, Charlottesville, VA 22908, USA) 6, 217 (1991)

Prone lateral radiograph in anorectal anomalies. Rao, K.L. N. (Dept. of Ped.Surg., Postgraduate Inst. of Med. Educat. and Res., Chandigarh, India) 6 , 235 (1991)

Fortschritte auf dem Gebiete der Röntgenstrahlen und der neuen bildgebenden Verfahren (Stuttgart)

Das Osteoidosteom der Wirbelsäule. Aktuelle differentialdiagnostische Aspekte. Lange, W. et al. (Abt. Rad. des Kreiskrankenhauses Marienhöhe, Mauerfeldchen 25, W-5102 Würselen, FRG) 154, 450 (1991)
RARE-MR-Urographie: Ein kernspintoomgraphisches Schnellbildverfahren zur Diagnostik von Harnwegsfehlbildungen im Kindesalter. Sigmund, G. et al. (Abt. Röntgendiagn., Rad.-Klin. der Univ. Freiburg, Hugstetterstr.55, W-7800Freiburgi.Br., FRG) 5,535 (1991)

\section{Gastrointestinal Radiology (Berlin)}

Caroli disease: Computed tomographic diagnosis. Sood, G.K. et al. (Dept. of Gastroenerology and Rad., G.B. Pant Hosp., New Delhi, India) 16, 243 (1991)

Gynäkologe (Berlin)

Der Stellenwert der Ultrasonographie in der Kinder- und Jugendgynäkologie. Pelzer, V. (Univ.-Frauenklin., Moorenstr. 5, W-4000 Düsseldorf, FRG) 24,91 (1991)

Die ultrasonographische Beurteilung von Adnextumoren im Kindesalter. Terinde, R. (Univ.-Frauenklin., Prittwitzstr. 43, W-7900 Ulm, FRG) 24, 97 (1991)

Kinderärztliche Praxis (Leipzig)

Das Caroli' Syndrom im Kindesalter. Übersicht und Bericht über einen Patienten mit unbalanciertem Karyotyp. Schrader, E. et al. (Kinderklin. der Charité, Schumannstr. 20/21, O-1040 Berlin, FRG) 59,97 (1991)

Rank of bronchography in infancy taking in special consideration nuclear medical preliminary examinations. Fein, R. et al. (Klin. f. Kinderheilkunde, Med. Akad., Emanuel-Larisch-Weg 17-19, O-3014 Magdeburg, FRG) 59, 139 (1991)

\section{Klinische Pädiatrie (Stuttgart)}

Kawasaki disease in the first six months of life. Limbach, H. G., Lindinger, A. (A.Lindinger, Univ.-Kinderklin., W-6650 Homburg/Saar, FRG) 203, 133 (1991)

Congenital pulmonary vein stenosis: a rare cause of pulmonary hypertension. Mühler, E. et al. (Klin. f. Kinderkardiol. der RWTH Aachen, Pauwelstr.30, W-5100 Aachen, FRG) 203, 137 (1991)

Sonographic and color/coded sonographicfindings in osteosarcoma. Wild,F.et al. (Klin.mit Poliklin. f. Kinder und Jugendliche, Univ. Erlangen-Nürnberg, Loschgestr. 15, W-8520 Erlangen-Nürnberg, FRG) 203, 155 (1991) 
curring in the anterior mediastinum [2]. Toour knowledge our patient may be the first reported case presenting with prolonged fever due to infection and secondary abscess formation in the teratoma.

The most frequent tumors of this area in childhood are neuroblastoma and other neurogenic tumors, more rarely duplication of the gastrointestinal tract [2].

Diagnosis of postero-inferior mediastinal mass which was suspected on ultrasonography was confirmed by CT. Accurate localization and relations to adjacent organs, together with confirmation of calcification and fat within the mass gave a likely diagnosis. Recognition of a probable abscess formation enabled the correct treatment to be established prior to operation.

\section{References}

1. Friedman AC, Pyatt RS, Hartmann DS, Downey EF, Olson WB (1982) CT of benign cystic teratomas AJR 138: 659

2. Grosfeld JL, Billmire DF (1985) Teratomas in infancy childhood. Current problems in cancer, Vol IX, No 9. Year Book Medical Publishers, Chicago, p 30
3. KarlSR, Dunn J (1985) Posterior mediastinal teratomas Pediatrics 20:508

4. Rabin CB, Baron MG (1980) Radiology of the chest, 2nd edn. Williams \& Wilkins, Baltimore London, p 561

5. Suzuki M. Takashima T, Itoh $\mathrm{H}$, ChoutohS, Kawamura I, Watanabec Y (1983) Computed tomography of mediastinal teratomas JCAT 7:74

Dr. A.H.Sidani

Service de Radiologie

Hôpital Régional de Sion

CH-1950 Sion

Switzerland

Literature in pediatric radiology (continued from $p .437$ )

Monatsschrift Kinderheilkunde (Berlin)

Das asymptomatische Moyamoya-Syndrom. Diagnose durch EEG und Magnetresonanzangiographie. Kurlemann, G. et al. (Univ.-Kinderklin., Albert-Schweitzer-Str. 33, W-4400 Münster, FRG) 139, 235 (1991)

Arthritis tuberculosa - eine seltene, aber wichtige Differentialdiagnose zur juvenilen chronischen Arthritis (JCA). Schuchmann, L. et al. (Arbeitsgemeinschaft Päd.-Rheumatol., Schwimmbadstr.24, W-7800 Freiburg, FRG) 139,244 (1991)

Early detection of changes in peripheral vessels of children and juveniles with insulin-dependent diabetes mellitus by Doppler ultrasound. Krause, M. et al. (Kinderklin. und Kinderpoliklin. der Univ. Josef-Schneider-Str.2, W-8700 Würzburg, FRG) 139,282 (1991)

Whiplash-shaken-infant syndrom - a special form of child abuse. Thyen, $U$., Tegtmeyer, (Klin. f. Päd., Med. Univ., Kahlhorststr.31-35, W-2400 Lübeck, FRG) 139,292 (1991)

\section{Neuropediatrics (Stuttgart)}

Pelizaeus-Merzbacher disease: Classical or connatal? Scheffer, I.E. et al. (M.Baraitser, Dept. of Clin. Genetics, The Hosp. for Sick Children, Great Ormond St., London, WC1N 3JH, England) 22, 71 (1991)

\section{Neuroradiology (Berlin)}

Computed tomography of intracranial tuberculosis. Jinkins, J. R. (Neurorad. Sect., Univ. of Texas Health Sci. Center, 7703 F. Curl Drive, San Antonio, TX 78284-7800, USA) 33,126(1991)

Paediatric medulloblastoma: atypical CT features at presentation in the SIOP II trial. Nelson, M. et al. (Sect. of Neurorad., The General Infirmary, Great George St., Leeds LS1 3EX, England) 33, 140 (1991)

MRI of two infants with tuberous scle rosis. Stricker, T. et al. (E. Martin, Univ.Kinderklin., Steinwiesstr.75, CH-8032 Zürich, Switzerland) 33, 175 (1991)

Resolving MRI abnormalities with progression of subacute sclerosing panencephalitis. Winer, J.B. et al. (Queen Elizabeth Hosp., Edgbaston, Birmingham B152TT, England) 33,178 (1991)

MR of progressive neurodegenerative change in treated Menkes' kinky hair disease. Johnsen, D.E. et al. (Rad. Dept., 20-07, Geisinger Med. Center, Danville, PA 17822, USA) 33, 181(1991)

MR imaging of intracranial hemorrhage in neonates and infants at 2.35 Tesla. Zuerrer, M. et al. (Dept. of Ped., Div. of Magnetic Resonance, Univ. of Zürich, Switzerland) 33,223 (1991)

Neuroimaging in lissencephaly type I. De Rijk-van-Andel. J. F. et al. (Dept. of Neural., Westeinde Hosp., The Hague, Netherlands) 33, 230 (1991)

Magnetic resonance imaging of the brain in congenital rubella virus and cytomegalovirus infections. Sugita, K. et al. (Dept. of Ped., Chiba Univ. Sch. of Med., Chiba, Japan) 33,239 (1991)

Intradiploic meningiomas. A radiological study of two cases confirmed histologically. Halpin, S.F.S. et al. (Dept. of Neurorad., Atkinson Morley's Hosp., Wimbledon, England) 33,247 (1991)

MRI of subarachnoid dissemination of medulloblastoma. Kochi, M. et al. (Dept. of Neurosurg., Kumamoto Univ. Med. Sch., 1-1-1 Honjo, Kumamoto 860, Japan) 33, 264 (1991)

MRI and pathological findings in two cases of Askin tumors. Faubert, C., Inniger, R. (Neurorad. Inst., Dept. of Pathol., Univ. of Saarland, Homburg-Saar, FRG) 33, 277 (1991)

\section{Der Orthopäde (Berlin)}

Orthopädische Probleme an der oberen Halswirbelsäule bei Kindern und Jugendlichen. Grob, D. et al. (Abt. f. Orthopäd. und Neurol., Klinik Wilhelm Schulthess, Zürich, Switzerland) 20, 133 (1991)
Pädiatrie (Karlsruhe)

The spleno-gonadal fusion. Wirth. $H$. et al. (Kinderchir.-Klin., Klinikum Mannheim der Univ. Heidelberg, Theodor-Kutzer-Ufer, W-6800 Mannheim 1, FRG) 4, 200 (1991)

Pädiatrische Praxis (München)

Knochenbefall bei Langerhans-Zell-Histiozytose (Histiozy tosis X). Krauspe R., Kühl, J. (Orthopäd. Univ.-Klin., Brettreichstr.11, W-8700 Würzburg, FRG) 42,43(1991)

Das Pancreas anulare, eine seltene kongenitale Anomalie. Reck, Th. et al (Chir.-Univ.-Klin., Maximiliansplatz, W-8520Erlangen,FRG) 42,91(1991)

"Adultrespiratory distresssyndrome"(ARDS)Hachenberg, T.etal.(Klin.und Poliklin.f.Anästh.und OperativeIntensivmed.derWestfälischenWilhelmsUniv., Albert-Schweitzer-Str.33, W-4400 Münster,FRG) 42,293 (1991)

Skapulafrakturen im Kindes- und Jugendalter. Sommerer, G. et al. (P.Klein, Chir.-Univ.-Klin., Maximiliansplatz, W-8520 Erlangen,FRG) 42,325 (1991)

Nekrotisierende Enterokolitis bei Frühgeborenen und jungen Säuglingen aus kinderchirurgischer Sicht. Dietz. H.G. (Kinderchir.-Univ.-Klin., Lindwurmstr. 4, W-8000 München 2, FRG) 42, 331 (1991)

Pediatric Nephrology (Berlin)

Renovascular hypertension: a rare cause of neonatal salt loss. Blanc. F. et al (Centre de Péd. E. Lesne, Hop. Trousseau, 26 Ave. Dr. A. Netter, F-75012 Paris, France) 5, 304 (1991)

Radiologia Diagnostica (Berlin)

Poland's syndrome. Tscherninkoff, Z., Raeva, D. (Iretschek 2, 8800 Sliven, Bulgaria) 32, 147 (1991)

Radiologie (Berlin)

Digital subtraction angiography in neuropediatric diseases. Beltramello, A. et al. (Serv. de Neurorad,, Osped. Maggiore, Piazzale Stefani 1, I-37134 Verona, Italy) 11, 45 (1991)

\section{Skeletal Radiology (Berlin)}

Case report 670: Chondroblastoma maxillary sinus. Martinez-Madrigal, F et al. (Dept. of Histopath., Rad. and Head and Neck Surg., Inst. GustavRoussy, Villejuif, France) 20,299 (1991)

Telangiectatic osteogenic sarcoma: Case report 673. Liu, S.-K., Thacher, Ch. (The Animal Med. Center, New York, NY, USA) 20,311(1991)

Lipoblastoma of knee: Case report 675. Ehara, S. et al. (Center for Rad. Sci. Sch. of Med., Iwate Med. Univ., 19-1 Uchimaru, Morioka, 020 Japan) 20,319 (1991)

Antley-Bixler syndrome: description of two patients. Bianchi, E. et al. (G. Beluffi, Sect. of Paed.-Rad.-Diagn., IRCCS Policlin. S. Matteo, I-27100 Pavia Italy) 20,339(1991)

Synovial hemangioma of the knee. Case report 681. Lenchik, L. et al. (Northwestern Univ. Med. Sch., Dept. of Rad.. Chicago, IL. USA) 20,387 (1991)

Distal metaphyseal femoral defect (cortical desmoid; distal femoral corticalirregularity). Case report 683. Sklar, D.H. et al. (Dept. of Rad., HarborUCLA Med. Center, Torrance, CA, USA) 20,394 (1991)

Infantilemyofibromatosis. Case report 684. Kozlowski, K. et al.(Dept. of Rad., Royal Alexandra Hosp. for Children, Camperdown, NSW 2050 Australia) 20,397 (1991)

Surgical Radiologic Anatomy (Berlin)

Antenatal diagnosis of abdominothoracic alimentary tract duplication: a case report. Jacquemard, F. et al. (J.M.Duval, Lab. d'Anatomie et Serv. des Ultra-sons, CHRU de Rennes, 2 rue Henri-Le-Guilloux, F-35033 Rennes, France) 13, 53 (1991) 
of mesenteric fibromatosis occurring in the absence of previous surgery [3].

A review of the Polyposis Registry at St Mark's Hospital, London revealed an association with thyroid carcinoma (particularly papillary carcinoma in women under 35 years) and recommended regular thyroid examination in all patients with adenomatous polyps [4]. Turcot's syndrome was originally described in 1959 with a report of two siblings with familial adenomatous polyposis one of whom had an associated medulloblastoma of the spinal cord, the other a glioblastoma of the frontal lobe. It has been suggested that the name Turcot's syndrome should be reserved for the association of FAP with medulloblastoma and glioblastoma only, and that other cases of association with astrocytoma, neurofibroma, craniopharyngioma etc. are not true examples of Turcot's syndrome [5]. Our case is the first report of familial adenomatous polyposis in association with rhabdomyosarcoma.

Acknowledgements. We wish to acknowledge the help of Dr. B.Sandhu, Consultant Pediatrician.

\section{References}

1. Lees C, Hermann R (1981)Familial polyposis coli associated with bile duct cancer. Am J Surg 141:378

2. Li FP, Thurber WA, Seddon J, Holmes GE (1987) Hepatoblastoma in families with polyposis coli. J Am Med Assoc 257: 2475

3. Suehiro S, Inai K (1987) Mesenteric fibromatosis in familial polyposis. A case report anda review of Japanese cases. Acta Pathol Jpn 37: 1837

4. Plail RO, Bussey HJ, Glazer G, Thomson JP (1987)Adenomatous polyposis: an association with carcinoma of the thyroid. $\mathrm{Br} \mathrm{J}$ Surg 74:377

5. Jarvis L, Bathurst N, Mohan D, Beckly D (1988) Turcot's syndrome. A review. Dis ColRect 31:907

\section{Dr. A. W. Duncan}

Department of Radiodiagnosis

Bristol Royal Hospital for Sick Children

St. Michael's Hill

Bristol BS28BJ

U.K.

\section{Literature in pediatric radiology (continued from $p .439$ )}

Abnormal direct entry of the umbilical vein into the right atrium: antenatal detection, embryologic aspects. Jouk, P.S., Champetier, J. (J.Champetier, Serv. de Méd. Néonatale, Unité d'Exploration Echographique, CHU de Grenoble, BP217X, F-38043 Grenoble, France) 13,59 (1991)

\section{Thoracic and Cardiovascular Surgeon (Stuttgart)}

Tracheal agenesis: An unresolved problem. Lopez, L. et al. (Unidad de Cirugia Torácica, Hosp. Ntra. Sra. del Pino, cl. Angel Guimerá 93, 35004 Las Palmas de Gran Canaria, Canary Islands) 39,99 (1991)

An unusual esophageal foreign body perforation - A case report and review of the literature. Al-Qudah, A. (P.O.Box 13255, Univ. of Jordan, Amman, Jordania) 39, 102 (1991)

Congenital pulmonary arteriovenous fistula: A rare cause of cyanosis in childhood. Batinica, S. et al. (Dept. of Ped. Surg., Clin. Fosp. Center, Univ. of Zagreb, Kisoatićeva 12, YU-41000Zagreb, Yugoslavia) 39, 105 (1991)

Urologic Radiology (Berin)

Imaging of neonatal renal masses. Fernbach, S. K. (Dept. of Rad., 9, The Children's Memorial Hosp., 2300 Children's Plaza, Chicago, IL 60614 USA) 12, 214 (1991)

Doppler examination of the kidney in infants and children. Patriquin, $\mathrm{H}$. (Dept. of Rad., Hôp. Ste-Justine, 3175 Côte Ste-Catherine, Montreal, Quebec, Canada H3T 1C5) 12, 220 (1991)

Imaging of uterovaginal anomalies in the pediatric patient. Shatzkes, D. R. et al. (J. O. Haller, Dept. of Rad., State Univ. of New York, Health Sci. Center at Brooklyn, NY11203, USA) 13, 58 (1991)

Zeitschrift fïr Orthopädie und ihre Grenzgebiete (Stuttgart)

The high arched forefoot. Steinwender, G., Linhart, W.E. (W.E.Linhart, Univ.-Klin. f. Kinderchir, Heinrichstr. 31, A-8010 Graz, Austria) 129, 240 (1991)

Pädiatrie und Pädologie (Wien)

Macrocephaly and dystonic cerebral palsy in a child with glutaric aciduria type I. Plöchl, E. et al. (Kinderspital der Landeskrankenanstalten Salzburg, Müllner Hauptstr. 48, A-5020 Salzburg, Austria) 26, 97 (1991)

JBR-BTR Journal Belge de - Belgisch Tijdschrift voor-Radiologie (Brussel)

Cervical intervertebral disc calcification in children: case report. Verhille, $R$. et al. (Dept. of Rad., Imeldaziekentuis, Imeldalaan 9, B-2820 Bonheiden, Belgium) 74, 109 (1991)

Ossifying fibroma of the long bones. Radiological diagnosis, differential diagnosis and management implications. Desprechins, B. et al. (Dept. of Rad., AZ-VUB, Laarbeeklaan 101, B-1090 Brussels, Belgium) 74, 121 (1991)

European Journal of Radiology (Amsterdam)

Normal brain maturation in MRI. Hayakawa, K. et al. (Dept. of Rad., Kyoto City Hosp., 1-2 Higashi-takada-cho, Mibu, Nakagyo-ku, Kyoto 604, Japan) 12,208(1991)

International Journal of Pediatric Oto- Rhino- Laryngology (Amsterdam) An enteric duplication cyst occurring in the anterior two-thirds of the tongue. Willner, A. et al. (ENT Dept., Montefiore Med. Center, Bronx, New York, NY 10467, USA) 21, 169 (1991)
Acta Paediatrica Scandinavica (Stockholm)

The risk of X-ray examinations of the lungs in neonates. Arrøe, M. (Dept. of Paed., Univ. Hosp. of Copenhagen, Hvidovre Hosp., DK-2650 Hvidovre, Denmark) 80, 489 (1991)

Coeliac disease, folic acid deficiency and epilepsy with cerebral calcifications. Ventura, A. et al. (Clin. Ped., Ist. per i'Infanzia Burlo Garofolo, via dell'Istria, 63/1, Trieste, Italy) 80, 559 (1991)

Diabetes insipidus, diabetes mellitus, optic atrophy and deafness (DIDMOAD syndrome) A clinical study in two Sudanese families. Salih, M.A.M., Tuvemo, T. (Dept. of Ped., Univ. Hosp., S-75185 Uppsala, Sweden) 80,567 (1991)

Quantitation of muscles and fat by ultrasonography: A useful method in the assessment of malnutrition in children. Koskelo. E.-K. et al. (Children's Hosp., Dept. of Diagn. Rad., Univ. of Helsinki, Heisinki, Finland) 80, 682 (1991)

Acta Radiologica (Copenhagen)

Diagnostic cyst puncture of multicystic kidney in neonates. Kullendorff, C. M. et al. (Dept. of Ped.-Surg., Univ. Hosp., S-221 85 Lund, Sweden) 31, 287 (1990)

The role of bone scintigraphy in predicting femoral head collapse following cervical fractures in children. Mortensson, W. et al. (Dept. of Ped.-Rad., St. Göran's Children's Hosp., S-11281 Stockholm, Sweden) 31,291 (1990)

Neonatal systemic candidiasis diagnosed by ultrasound. Tung, K. T. et al. (Dept. of Rad., Wesiminster Hosp., Dean Ryle St., Horseferry Road, London SW1P2Ap, England) 31, 293 (1990)

Iohexol for contrast enhancement of bowel in pediatric abdominal CT. Smevik, B., Westvik, J. (Dept. of Ped.-Rad., The National Hosp., Oslo, Norway) 31, 601 (1991)

Pediatrician (Basel)

Late effects of radiation therapy. Constine, L. S. (Dept. of Rad. Oncol, and Ped.. Univ, of Rochester Med. Center, 601 Elmwood Ave., Box 647, Rochester, NY 14642, USA) 18,37(1991)

Minerva Pediatrica (Torino)

Linfoma non-Hodgkin con interessamento epatosplenico. Importanza della diagnostica per immagini mediante tomografia a risonanza magnetica. Lucigrai, G. et al. (Serv. di Rad., Ist. "G. Gaslini", Largo Gaslini, 5, I-16148 Genova, Italy) 43, 323(1991)

Nefroma cistico multiloculare in età pediatrica. Presentazione di un caso. Sorrentino, G. et al. (Falzoni, P., Via Cavour, 30, I-27024 Cilavegna (PV), Italy) 43,329(1991)

Megaesofago acalasico ad insorgenza nel I annodi vita. Descrizione di un caso. Pellegrino, M. etal. (Div.diPed., Osped.Gen.Reg. "Casa Sollievo della Sofferenza", I-71013 S. Giovanni Rotondo (FG), Italy) 61,453 (1991)

Diagnosi ecografica di cistite da Candida albicans in età pediatrica. Bergami, G. et al. (Via Aladino Govoni, 34, I-00136 Roma, Italy) 91,389 (1991)

Le malformazioni artero-venose endocerebrali (MAV). Lazzaroni-Fossati, $F$. et aI. (Via Martiri della Libertà, 33/A, I-16156 Genova, Italy) 91, 399 (1991)

Torsione degli annessi in età pediatrica. Sorrentino, G. et al. (P. Falzoni, Via Cavour, 30, I-27024 Cilavegna, Italy) 91, 409 (1991) 
Blood cultures for bacteria, fungi and viruses were all negative. Serology for viruses was negative. Several bone biopsies revealed only non-specific inflammatory changes. Immunological studies were normal. X-rays revealed metaphyseal lucencies with adjacent periosteal elevations. Pathological fractures were noted at the distal ulna of the left arm (Figs.1,2). The axial skeleton, spine, pelvis and skull, were never affected. During a period of ten months, although she received several antibiotics, aspirin and steroids, swelling of the limbs remained unchanged.

X-rays of her limbs at the age of 1 year demonstrated tremendous bone changes. There was loss of normal bone modeling with extensive periosteal overgrowth(Figs. 3,4). Repeat bone biopsy with electromicroscopy study showed distinct particles in the mitochondria, compatible with viral inclusions. Bone-tissue cultures for viruses were negative.

Anti-viral therapy with Acyclovir, and later Interferon did not have any beneficial result.

During four years of follow-up, no remission has occurred. The child remains crippled and bed-ridden, although her mental development is normal.

\section{Discussion}

The clinical, radiological and histological findings in the above case are compatible with a diagnosis of chronic recurrent multifocal osteomyelitis. However, the excessive severe periosteal overgrowth is similar to the tumorous osteomyelitis published by Kozlowski [4]. Differential diagnosis includes those diseases with periosteal hypertrophy like Caffey's disease, Goldbloom's syndrome, diffuse sclerosing osteomyelitis (Garre's disease) and hyperostosis hyperphosphatemia syndrome.

The patient's disease started with metaphyseal destructive lesions, which are not a manifestation of Caffey's disease or Garre's osteomyelitis. She did not have any dysproteinemia or hyperphosphatemia to support the other entities $[5,6]$.

In the reported cases, no causative infective agent was ever found, yet Kozlowski et al. [3] and Speer [7] consider CRMO to be an infectious disease. We believe that the electromicroscopic findings suggest a viral etiology. The severe limb deformity, including overgrowth of the metacarpals and fingers, resulted in a crippled, bed ridden child, which is unusual in CRMO.

\section{References}

1. Giedion A, Holthusen W, Masel LF, et al. (1972) Subacute and chronic "symetrical" osteomyelitis. Ann Radiol 15: 329
2. King SM, Laer RM, Manson D, et al. (1987) Chronic recurrent multifocal osteomyelitis. A noninfectious inflammatory process. Pediatr Infect Dis J 6: 907

3. Kozlowski K, Masel J, Harbison S, et al. (1983) Multifocal chronic osteomyelitis of unknown etiology. Report of five cases. Pediatr Radiol 13:130

4. Kozlowski K, Anderson RJ, Hochberger O, et al. (1984) Tumerous osteomyelitis. Pediatr Radiol 14: 404

5. Gerscovich EO, Greenspan A, Lehman WB (1990) Idiopathic periosteal hyperostosis with dysproteinemia (Goldbloom's syndrome). Pediatr Radiol 20:208

6. Cameron BJ, Laxer RM, Wilmot DM, Greenberg ML, Stein LD (1987) Idiopathic periosteal hyperostosis with dysproteinemia (Goldbloom's syndrome) Arthritis Rheum 30:1307

7. Speer DP (1984) Chronic multifocal symetrical osteomyelitis editorial. Am J Dis Child 138:340

\section{R. Starinsky, MD}

Department of Diagnostic Radiology

Assaf Harofeh Medical Center

Zerifin 70300

Israel
Radiologia Medica (Torino)

Rhizomelic bone dysplasia with club-like femora. A distinctive, easily recognisable disease. Case report. Gugliantini, P. et al. (K. Kozlowski, RAHC, Camperdown 2050, Sydney, NSW, Australia) 81,550 (1991)

Errori nell'ecografia dell'anca neonatale. Rabassini, A. et al. (Via Montello 6/E, I-31100 Treviso TV, Italy) 81,609 (1991)

\section{Radiologia (Madrid)}

Baker's cyst during infancy: ultrasonographic assessment. Moragón, C.L.M. et al. (Avda. de España, 13, E-02002 Albacete, Spain) 33, 271 (1991)

Gastric teratoma. Astolfi, J.I.M. et al. (Periodista Ramón Resa, 8, 6. ${ }^{\circ}$ A., E-41012 Sevilla, Spain) 33,291 (1991)

Lesiones de mandibula y maxilar superior en la infancia. Méndez, E. V. et al. (Serv. de Rad., Hosp. Infantil, C.S. Valle de Hebrón, E-08035 Barcelona, Spain) 33,335 (1991)

Imagen por resonancia magnética de las malformaciones congénitas del sistema nervioso central. Jaureguizuria, J.C.R., Collado, A.F. (Centro de Resonancia Magnética, Clin. San Francisco Javier, Gordóniz, 12, E-48010 Bilbao, Spain) 33, 369 (1991)

1991 Year Book of P.R. - Current problems of Pediatric Radiology (Miskolc)

The differences between paediatric and adult radiology. Sweet, E. M. (Dunwhillan, 3 Fullarton Crescent, Troon, Ayrshire, KA 10 6LL, England) Volume 3,1 (1991)

Rational approach to vascular rings in children. Gyepes, N. T. et al. (Dept. of Ped.-Rad.,MemorialHosp.Med.Center, Memorial Millerchildren's Hosp. 2801 Atlantic Ave., Long Beach, CA 90801, USA) Volume 3,7 (1991)

The non skeletal injuries of child abuse. Part I. The brain. Carty H. (Dept. of Rad., Royal Liverpool Childrens Hosp. Alder Hey, Eaton Road, Liverpool L122AP, England) Volume 3, 17 (1991)

The non skeletal injuries of child abuse. Part II. The body. Carty, H. (Dept. of Rad., Royal Liverpool Childrens Hosp. Alder Hey, Eaton Road, Liverpool L122AP, England) Volume 3,25 (1991)

Plain X-ray film of the chest as a clue to bone dysplasias diagnosis in pediatric patients. Beluffi, G. (Sect. of Ped.-Rad., Dept. of Radiodiagnosis, Ped. Clin. of the Univ., IRCCS Policlin. S. Matteo, I-27100 Pavia, PV, Italy) Volume 3 35 (1991)

Pelvic masses in children: Sonographic appearance. Kis, É, et al. (Budapest, H-1083 Üloi u. 78/a, Clin. of Rad., Semmelweis Med. Univ., Hungary) Volume 3, 43 (1991)

Oto-palato-digital syndrome in a large Italian family. Beluffi, G. et al. (Sect. of Ped.-Rad., Dept. of Radiodiagnosis, Ped. Clin. of the Univ., IRCCS Policlin. S. Matteo, Italien, I-27100 Pavia, PV, Italy) Volume 3,49 (1991)

Ultrasound diagnosis of duodenal duplication. Bruno, M. A., Gyepes, M.T. (Dept. of Rad., Mem. Miller Childrens' Hosp., Long Beach, CA 90801, USA) Volume 3, 55 (1991)

Traumatic epidural hemorrhage with extensive blood loss in an infant. Velkey, I. et al. (Child Health Center, H-3501 Miskolc, POB 188, Hungary) Volume 3, 63 (1991)

Successful operation of huge malignant choroid plexus papilloma. Dobai, J.et al. (Dept. of Neurosurg., County Teaching Hosp., H-3501 Miskolc, POB 188, Hungary) Volume 3,67 (1991)

Imaging technology and medicine. Kormos, I., Feher, A. (Protomix Ltd. Kondorfa str. 10, H-1116 Budapest, Hungary) Volume 3, 73 (1991)

Pediatrie (București)

Clinical radiological aspects in the tuberculosis of the infant and small child. (Spitalul Judetean Bistrita, Rumania) 39, 165 (1990)

Intravesical foreign body. - Cause of chronic pyelonephritis in a child. Sabǎu, I. et al. (Clin. de Ped. I, Timioara, Rumania) 39,173 (1990)

A case of pycnodysostosis (radioclinical characteristics). Leu, E.Gh. et al. (Spitalul clin. de Copii, Iași, Clin. a II-a, Rumania) 39, 181 (1990)

Radiologia Iugoslavica (Ljubljana)

Spectin diagnosis of Legg-Calve-Perthes disease (comparison with planar and pinhole scintigraphy). Dodog, D. et al. (Dept. of Nuclear Med., Univ. Hosp. Rebro, Kispaticeva 12, YU-41000 Zagreb, Yugoslavia) 25, 35 (1991)

Anomalies of intestinal rotation and fixation in radiological findings. Simunic, F. et aì. (M. Frković, Maksimirska cesta 12/1, YU-41000 Zagreb, Yugosiavia) 25, 103 (1991) 